\title{
Spatial variation in otolith elemental composition of the Pacific herring Clupea pallasii in northern Japan
}

\author{
Kodai Yamane ${ }^{1, *}$, Kotaro Shirai ${ }^{2}$, Yoshitomo Nagakura ${ }^{3}$, Motohito Yamaguchi ${ }^{4}$, \\ Akio Takiya ${ }^{4}$, Takashi Horii ${ }^{5}$, Nobuyuki Tanaka ${ }^{6}$, Sachinobu Yamane ${ }^{1}$, Takaomi \\ Arai $^{1}{ }^{1}$, Tsuguo Otake ${ }^{1}$ \\ ${ }^{1}$ International Coastal Research Center, Atmosphere and Ocean Research Institute, the University of Tokyo, Akahama, \\ Otsuchi, Iwate 028-1102, Japan \\ ${ }^{2}$ Department of Earth and Planetary Science, Graduate School of Science, the University of Tokyo, Hongo, Bunkyo-ku, \\ Tokyo 113-0033, Japan \\ ${ }^{3}$ Miyako Station, National Center for Stock Enhancement, Fishery Research Agency, Sakiyama, Miyako, \\ Iwate 027-0097, Japan \\ ${ }^{4}$ Central Fisheries, Research Institute, Hokkaido Research Organization, Hamanaka, Yoichi, Hokkaido 046-8555, Japan \\ ${ }^{5}$ Kushiro Fisheries, Research Institute, Hokkaido Research Organization, Hama-cho, Kushiro, Hokkaido 085-0024, Japan \\ ${ }^{6}$ Abashiri Fisheries, Research Institute, Hokkaido Research Organization, Masuura, Abashiri, Hokkaido 099-3119, Japan
}

\begin{abstract}
In order to examine whether otolith elemental composition of Pacific herring Clupea pallasii reflected spatially specific differences in capture location, we analyzed the elemental compositions in the edge portion of each otolith, which corresponded to the period immediately prior to the capture, as an indicator of the geographic areas in which the outer otolith was deposited. We collected 7 fish groups from 5 coastal sites: Tomamae offshore, Ishikari Bay, Akkeshi Bay, Lake Furen and Miyako Bay along the Japanese coast. Six elemental ratios, $\mathrm{Na} / \mathrm{Ca}, \mathrm{Mg} / \mathrm{Ca}, \mathrm{K} / \mathrm{Ca}, \mathrm{Cu} / \mathrm{Ca}, \mathrm{Sr} / \mathrm{Ca}$ and $\mathrm{Ba} / \mathrm{Ca}$, were measured in the edge areas of each otolith by laser ablation inductively coupled plasma mass spectrometry (LA-ICP-MS). Significant differences were shown in all mean elemental ratios of otoliths among 4 sampling groups in the 2005 year class and among 3 sampling groups in the 2006 year class. The classification accuracy with the jackknife cross-validation using quadratic discriminant function analysis ranged from 80 to $98 \%$ and 78 to $100 \%$ in the 2005 and 2006 year classes, respectively. Our findings are comparable to those in previous studies and are further evidence that otolith chemistry is a potential tool for identifying the Pacific herring groups with different habitatuse histories and migration patterns.
\end{abstract}

KEY WORDS: Laser ablation inductively coupled plasma mass spectrometry (LA-ICP-MS) · Otolith chemistry $\cdot$ Pacific herring $\cdot$ Population structure $\cdot$ Movement

\section{INTRODUCTION}

The Pacific herring Clupea pallasii is widely distributed in the northern part of the Pacific Ocean (Hay 1985). This species is a valuable commercial resource and an important forage species. It is therefore necessary to carry out effective fishery management based on reliable ecological information, such as the population structure and the movement of individuals. Pacific herring is distributed in the northern parts of Japan and several populations exist with different morphologies, genetics and spawning areas (Kanno 1989a,b, Kobayashi et al. 1990, Sugaya et al. 2008). Additionally, each population has independently greatly fluc- 
tuated in size (Iizuka \& Morita 1991, Nagasawa 2001), which possibly affects the fluctuation of the total abundance of the species. In order to understand the population dynamics of Pacific herring, it is important to discriminate each ecologically different population and to determine the migration patterns for feeding and spawning in coastal and oceanic habitats.

In previous studies, the population structure and the movements of Pacific herring were examined using artificial tags and genetics (Grant \& Utter 1984, Kobayashi et al. 1990, Hay et al. 2001, Sugaya et al. 2008). Artificial tagging methods however, can only link a recaptured fish to the geographic area where it was marked. Furthermore, they are impractical for smallsize fishes because of the high rates of mortality during early life stages, and because of the requirement of a large number of tagged individuals to ensure a sufficient number of recaptures. Genetic composition can link fish to their origin populations, but not to the geographic areas where it was distributed. In Pacific herring, therefore, alternative approaches are required for studying the population structure and the movements of individual fish.

To date, the chemical compositions of otoliths of teleost fishes have been analyzed to elucidate ecological questions concerning their population structure (Campana et al. 1994, Milton et al. 1997), population connectivity (Gillanders 2002), migration (Limburg 1995, Secor et al. 2001, Arai et al. 2004), the onset of metamorphosis (Otake et al. 1994, Arai et al. 1997), natal origin (Ruttenberg \& Warner 2006) and natal homing (Thorrold et al. 2001). Otoliths are composed of calcium carbonate crystals within a protein matrix and enable hearing and balance. They are formed prior to birth and grow with the daily deposition of a new crystal layer around the surface. Otolith elemental composition reflects environmental factors such as water temperature, salinity and elemental composition in the ambient water at the time of deposition (Townsend et al. 1992, Fowler et al. 1995, Hoff \& Fuiman 1995, Bath et al. 2000, Elsdon \& Gillanders 2002, Martin \& Thorrold 2005). Furthermore, since otoliths are metabolically inert, the otolith elemental composition remains unvaried after deposition and preserves a record of the environmental conditions experienced by the fish. In a number of previous studies, differences in elemental compositions of otoliths have been observed among different rivers (Thorrold et al. 1998a,b), estuaries (Gillan- ders \& Kingsford 1996) and oceanic areas (Ashford et al. 2005). Therefore, the elemental composition of fish otoliths can be useful as a natural tag for determining the geographic areas or habitats that have been used by each individual fish.

The objective of the present study was to examine whether otolith elemental composition of the Pacific herring reflected spatially specific differences in capture location. We analyzed the elemental compositions in the edge portion of each otolith, which corresponds to the period immediately prior to capture and serves as an indicator of the geographic area in which the outer otolith was deposited.

\section{MATERIALS AND METHODS}

Study sites and fishes. We sampled fish from 5 coastal sites: Tomamae offshore, Ishikari Bay, Akkeshi Bay, Lake Furen and Miyako Bay (Fig. 1). Four sampling sites were in the coastal waters off Hokkaido Island, and Miyako Bay was on the northeastern coast of Honshu. All sites except Tomamae offshore were major spawning grounds for Pacific herring Clupea pallasii. Furen Lake included brackish sites adjoining the Okhotsk Sea. Akkeshi Bay was also affected by brackish water from the adjoining
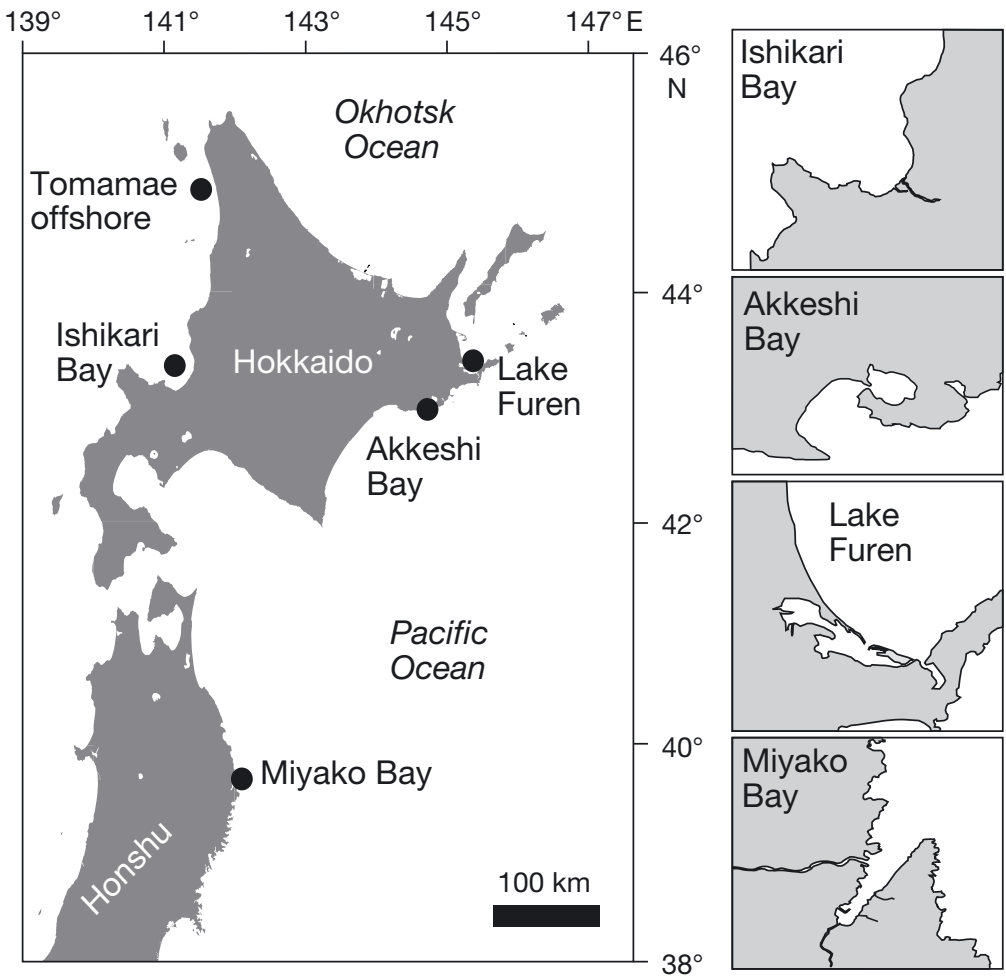

Fig. 1. Clupea pallasii. Location of the 5 sampling sites (0) used in the present study 
Akkeshi Lake. Ishikari Bay and Miyako Bay contained mostly full-strength seawater. However, since several rivers flowed into these bays, these sampling sites were affected to some degree by riverine freshwater. There is therefore, a potential for large differences in water chemistry among the 5 sites that may cause considerable differences in otolith elemental signatures.

Adult herring were collected from the 5 sites from late January to early June 2008, which is the spawning season of Pacific herring along the Japanese coast. All sampling sites, except Tomamae offshore, are major spawning grounds for Pacific herring on the Japanese coast. Therefore, it is highly likely that the collected fish came from the geographically corresponding spawning population. In Ishikari Bay, fish from the 2005 year class were collected twice, in both March and May, and 2 year classes were examined from the Miyako Bay site. This resulted in sampling groups being obtained from 5 sites in 2008, with 1 site being sampled for the same year class in 2 different months, and 2 year classes being sampled at 1 site, resulting in 7 sampling groups from 5 locations.

For each fish, total length (TL), fork length (FL) and gonad weight were measured and subsequently the gonad-somatic index (GSI; gonad weight $\times 100$ body weight ${ }^{-1}$ ) was determined. Year class was determined by counting the translucent bands in the otoliths or by counting the annuli of scales. The degree of gonad maturation was determined based on the GSI following Koya et al. (2003). Both TL and FL were measured in the 2006 year class of herring from Akkeshi Bay and Miyako Bay, but only either TL or FL was measured in the 2005 year class from Ishikari Bay in March, Ishikari Bay in May, Tomamae offshore, Miyako Bay and Lake Furen. We estimated the unmeasured values of either TL or FL of those individuals based on a linear regression analysis between TL and FL using herring from the 2006 year class in Akkeshi Bay and Miyako Bay (Fig. 2). The biological features of fish used in the present study, including sampling date, year class, TL, FL, sex and GSI, are summarized in Table1.

Otolith preparation and chemical analysis. Both sagittal otoliths from each fish were extracted, cleaned with Milli-Q water for $5 \mathrm{~min}$ in an ultrasonic bath, rinsed several more times in MilliQ water, and were then air-dried and placed in a clean plastic case. Prior to chemical analysis using laser ablation induc-

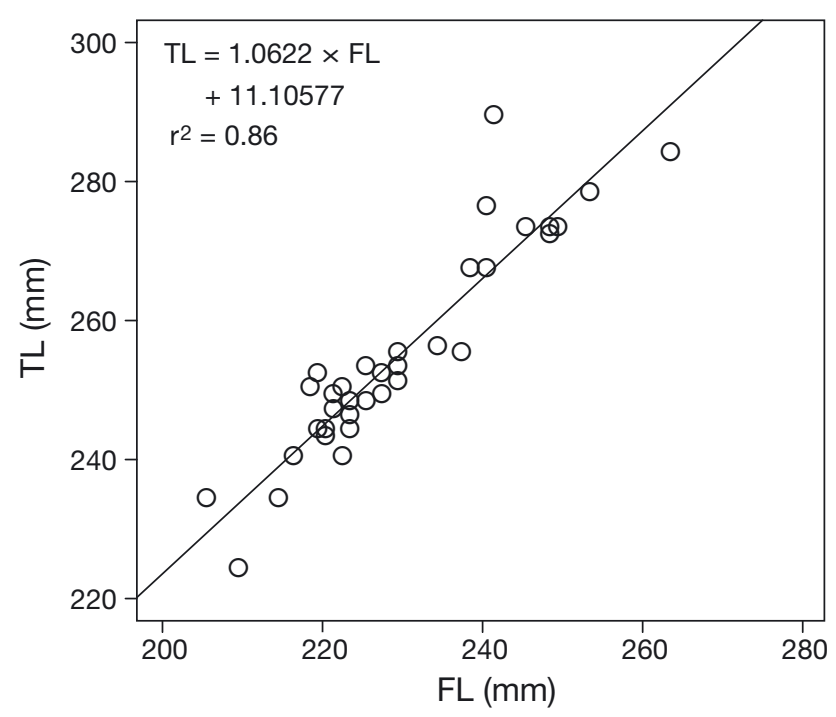

Fig. 2. Clupea pallasii. Results of linear regression analysis between total length (TL) and fork length (FL) using 2006 year class fish collected from Akkeshi and Miyako Bays

tively coupled plasma mass spectrometry (LA-ICP-MS), we set the otolith in the laser ablation chamber using double-sided tape without grinding and polishing.

Seven isotopes, ${ }^{23} \mathrm{Na},{ }^{24} \mathrm{Mg},{ }^{39} \mathrm{~K},{ }^{43} \mathrm{Ca}_{1}{ }^{63} \mathrm{Cu},{ }^{88} \mathrm{Sr}$ and ${ }^{138} \mathrm{Ba}$, were measured in the edge areas of each otolith by LA-ICP-MS. The LA-ICP-MS system used was the $7500 C S$ ICP-MS (Agilent) coupled with the $213 \mathrm{~nm}$ Nd-YAG laser ablation system (New Wave Research). To improve the measurement accuracy, we applied both the He flushing technique and a stabilizer device (Tunheng \& Hirata 2004). Calibration from the signal intensity to the element was performed using 4 standard materials, such as a clear calcite with known composition (Shirai et al. 2008a), NIST 612 standard glass

Table 1. Clupea pallasii. Specimens used for otolith elemental analysis. Sampling date, year class (YC), total length (TL), fork length (FL), number of individuals analyzed and gonad somatic index (GSI) are shown. TL, FL and GSI are presented as mean values $( \pm \mathrm{SD})$. The 7 sampling groups collected from 5 sampling sites were defined as Akkeshi Bay (A), Ishikari Bay in March (I-Mar), Ishikari Bay in May (I-May), Tomamae offshore (T), Miyako Bay in January (M-Jan), Miyako Bay in March (MMar) and Lake Furen (F). All fishes were captured in 2008. *indicates that the values were calculated from FL (or TL) based on the relationship between TL and FL in individuals of the 2006 year class from Akkeshi and Miyako Bays (see Fig. 2)

\begin{tabular}{|lccccccc|}
\hline Group & Date & YC & $\begin{array}{c}\text { TL } \\
(\mathrm{mm})\end{array}$ & \multicolumn{1}{c}{$\begin{array}{c}\text { FL } \\
(\mathrm{mm})\end{array}$} & $\begin{array}{c}\text { Male } \\
(\mathrm{n})\end{array}$ & $\begin{array}{c}\text { Female } \\
(\mathrm{n})\end{array}$ & $\begin{array}{c}\text { GSI } \\
(\%)\end{array}$ \\
\hline I-Mar & 26 Mar & 2005 & $291.3 \pm 8.1^{*}$ & $263.8 \pm 7.6$ & 6 & 15 & $20.7 \pm 4.4$ \\
I-May & 29 May & 2005 & $256.5 \pm 7.1^{*}$ & $231.0 \pm 7.1$ & 12 & 14 & $16.9 \pm 3.2$ \\
T & 16 Mar & 2005 & $276.8 \pm 6.7^{*}$ & $250.1 \pm 6.3$ & 4 & 16 & $15.0 \pm 1.8$ \\
M-Jan & 31 Jan & 2005 & $309.9 \pm 17.0$ & $281.2 \pm 16.0^{*}$ & 2 & 13 & $21.2 \pm 3.7$ \\
A & 1 Jun & 2006 & $249.7 \pm 9.1$ & $225.9 \pm 9.0$ & 9 & 9 & $16.1 \pm 2.4$ \\
M-Mar & 3 Mar & 2006 & $265.5 \pm 20.5$ & $239.0 \pm 18.8$ & 8 & 11 & $16.3 \pm 3.4$ \\
F & 24 Apr & 2006 & $263.0 \pm 9.1^{*}$ & $237.1 \pm 8.5$ & 11 & 10 & $17.4 \pm 5.3$ \\
\hline
\end{tabular}


distributed by the National Institute of Standards and Technology (USA), and pressed pellets of certified reference material of powdered coral (JCp-1) and powdered giant clam (JCt-1) distributed by the National Institute of Advanced Industrial Science and Technology (Japan) (Shirai et al. 2008b). The standard used in each analysis was chosen depending on the elemental properties of each standard material.

We made duplicate $40 \mu \mathrm{m}$ diameter laser beam spot measurements at the edge of each otolith. The ablated areas covered about $10 \mathrm{~d}$ prior to the capture, since we determined 10 otolith daily rings in these areas through light microscope observations. The frequency of the laser beam was $10 \mathrm{~Hz}$. The predicted crater depth was approximately $50 \mu \mathrm{m}$. The elemental data of each otolith were presented as the average of 2 spots. Otoliths from different sampling sites were randomly analyzed throughout the analysis. Background levels and standard references were examined before and after each scan. The isotope ${ }^{43} \mathrm{Ca}$ was used as an internal standard, and all elemental data were expressed in terms of their molar ratio to $\mathrm{Ca}$. The detection limits achieved in the present study were as follows: ${ }^{23} \mathrm{Na}$ $66.24,{ }^{24} \mathrm{Mg} \mathrm{2.06},{ }^{31} \mathrm{P} 18.73,{ }^{39} \mathrm{~K} 27.69,{ }^{63} \mathrm{Cu} 0.16,{ }^{88} \mathrm{Sr}$ 0.010 and ${ }^{138} \mathrm{Ba} 0.013 \mu \mathrm{mol} \mathrm{mol}{ }^{-1}$. These values were calculated from 3 standard deviations from the mean blank count of each isotope (gas background). All sample compositions were above the limit of detection. Mean estimates of precision (\%, relative standard deviation) based on JCp-1 standard were $2.67 \%$ $(\mathrm{Na} / \mathrm{Ca}), 2.36 \%(\mathrm{Mg} / \mathrm{Ca}), 6.76 \%(\mathrm{~K} / \mathrm{Ca}), 7.31 \%(\mathrm{Cu} / \mathrm{Ca})$, $3.50 \%(\mathrm{Sr} / \mathrm{Ca})$ and $9.35 \%(\mathrm{Ba} / \mathrm{Ca})$.

Data analysis. The differences in the content of each element in the otolith among 7 sampling groups (Table 1) were tested using ANOVA and, subsequently, Tukey and Kramer's multiple comparisons among sampling groups. A multivariate analysis of variance (MANOVA) was performed to examine the geographic variations among 5 sampling groups. It was also used for examination of the monthly variation in otolith chemistry within a single sampling site using the fish groups collected from Ishikari Bay in March and May. To examine whether otolith chemistry discriminates their habitat differences, we used quadratic discriminant function analysis (QDFA) of multi-signatures for each sampling group. We tested the ability of otolith elemental compositions to discriminate habitat differences using QDFA with jackknife cross validation.

Prior to analyses of data by ANOVA and QDFA, all elemental data were examined for normality and homogeneity of variances using either Shapiro-Wilk normality tests $(\alpha=0.05)$ or Bartlett tests $(\alpha=0.05)$. To meet model assumptions, the data were transformed into natural $\log$ values of $\mathrm{Na} / \mathrm{Ca}, \mathrm{K} / \mathrm{Ca}$ and $\mathrm{Sr} / \mathrm{Ca}$ ratios or reciprocally transformed values of $\mathrm{Mg} / \mathrm{Ca}, \mathrm{Cu} / \mathrm{Ca}$ and $\mathrm{Ba} / \mathrm{Ca}$ ratios. Normality was obtained for all 6 elemental ratios after the transformations. However, otolith $\mathrm{Mg} / \mathrm{Ca}, \mathrm{K} / \mathrm{Ca}$ and $\mathrm{Cu} / \mathrm{Ca}$ ratios were still heterogenous in variance, and a more constructive probability of $\alpha=0.01$ was used (Underwood 1999) for ANOVA. QDFA does not assume homogeneity of the covariance matrices; hence, QDFA was selected for classification methods.

\section{RESULTS}

We examined the difference in each elemental ratio of the edge areas of otoliths among 7 sampling groups of Pacific herring Clupea pallasii collected from different sampling localities and months (Table 1). Significant differences were shown in all mean elemental ratios of otoliths among 4 sampling groups in the 2005 year class, including Tomamae offshore, Ishikari Bay in March, Ishikari Bay in May and Miyako Bay in January (ANOVA, p < 0.001) (Fig. 3, Table 2). Tukey and Kramer's tests demonstrated that $\mathrm{Na} / \mathrm{Ca}, \mathrm{K} / \mathrm{Ca}$ and $\mathrm{Ba} / \mathrm{Ca}$ ratios of otoliths were significantly different among several sampling groups. In particular, the $\mathrm{Ba} / \mathrm{Ca}$ ratios for Ishikari Bay in May were considerably higher than those for the other groups. The $\mathrm{Mg} / \mathrm{Ca}$ ratios of otoliths collected from Miyako Bay in January were significantly lower than those for other sampling grounds. For the $\mathrm{Cu} / \mathrm{Ca}$ ratio, higher values were found at Ishikari Bay in March and May than at Tomamae offshore and Miyako Bay in January. The Sr/Ca ratios for Ishikari Bay were significantly higher than those for the other sites. Three sampling groups of the 2006 year class, including Akkeshi Bay, Lake Furen and Miyako Bay in March, also showed significant differences for all elemental ratios of otoliths (ANOVA; $\mathrm{p}<0.01$ ) (Fig. 3, Table 3). Tukey and Kramer's tests revealed that the $\mathrm{Na} / \mathrm{Ca}$ and $\mathrm{K} / \mathrm{Ca}$ ratios of the otoliths were significantly different among all sampling groups. There were significant differences in the $\mathrm{Mg} / \mathrm{Ca}$ ratios between Akkeshi Bay and Miyako Bay in March and between Miyako Bay in March and Lake Furen. The Sr/Ca ratios for Akkeshi Bay were significantly higher than those for Miyako Bay in March and Lake Furen. The $\mathrm{Cu} / \mathrm{Ca}$ ratios were considerably higher for Lake Furen than those for the other sampling groups. The $\mathrm{Ba} / \mathrm{Ca}$ ratios for Miyako Bay in March were significantly lower than those for Akkeshi Bay and Lake Furen. In multi-element fingerprints, the significant differences of otolith chemistry among sampling groups were shown in the 2005 year class (MANOVA, Pillai's trace $=1.98, \mathrm{p}<0.001$ ) and in the 2006 year class (MANOVA, Pillali's trace = 1.45, $\mathrm{p}<0.001)$. Furthermore, a MANOVA also showed a significant difference between fishes from Ishikari 

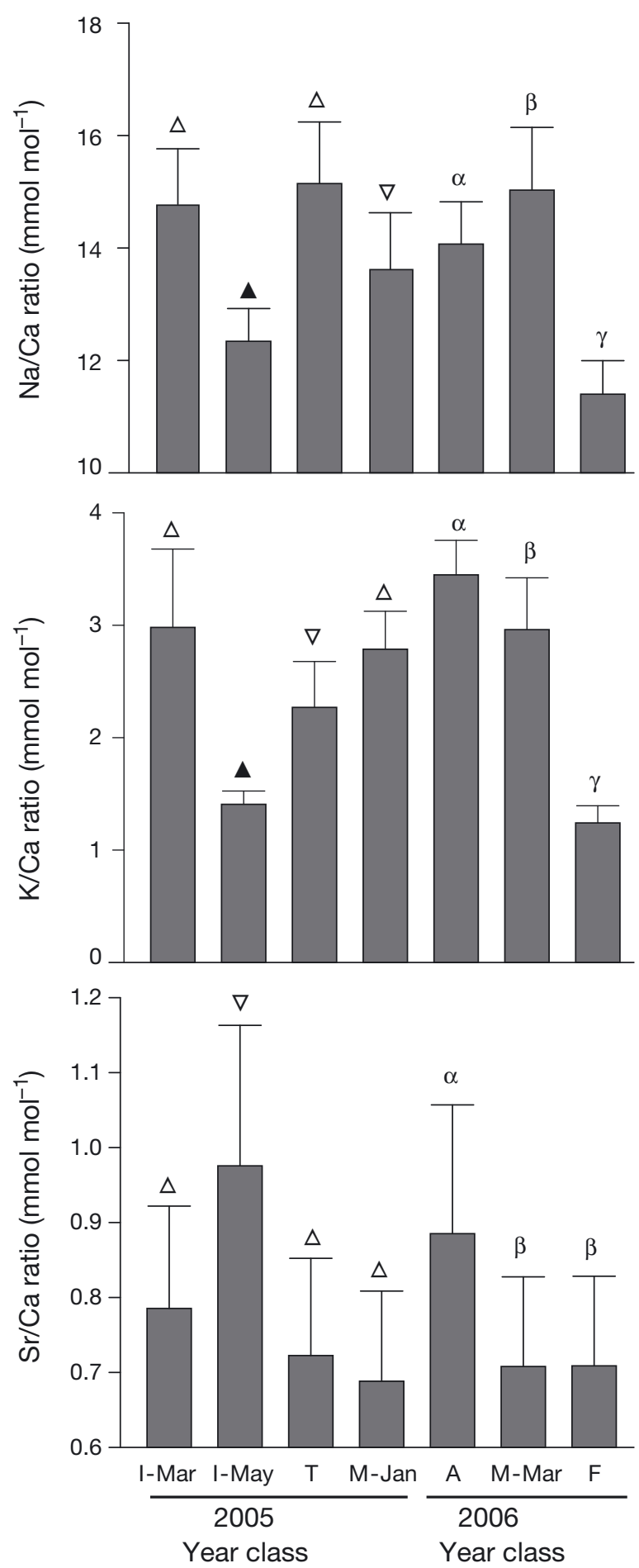
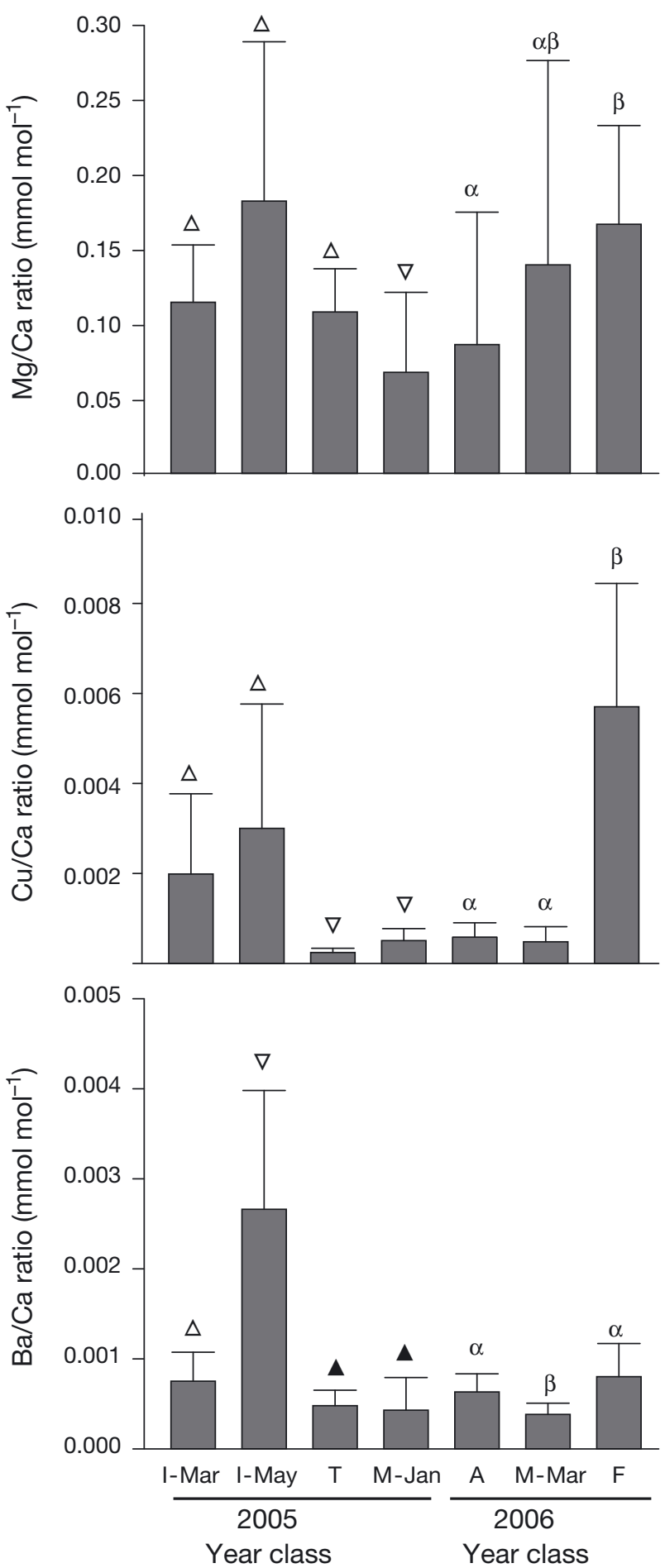

Fig. 3. Clupea pallasii. Otolith elemental ratios (mean +SD) of 7 sampling groups of Pacific herring: Ishikari Bay in March (I-Mar), Ishikari Bay in May (I-May), Tomamae offshore (T), Miyako Bay in January (M-Jan), Akkeshi Bay (A), Miyako Bay in March (MMar) and Lake Furen (F). Statistical differences are shown by different symbols $(\Delta, \nabla$ and $\mathbf{\Delta})$ for the 2005 year class and by Greek letters $(\alpha, \beta$ and $\gamma$ ) for the 2006 year class (post hoc multiple comparisons were made with Tukey and Kramer's tests)

Bay in March and May in the 2005 year class (Pillali's trace $=1.61, \mathrm{p}<0.001)$. Those results suggest that there are significant monthly and geographical variations in otolith chemistry in the Pacific herring.
QDFA was performed to determine the ability of elemental signature to classify adult fish to the correct localities where they were captured. In the 2005 year class, the classification accuracy examined by jack- 
Table 2. Clupea pallasii. Results of ANOVA for each element (molar ratio to calcium) in the otoliths of 4 sampling groups (Tomamae offshore, Ishikari Bay in March, Ishikari Bay in May, Miyako Bay) of the 2005 year class

\begin{tabular}{|lccccc|}
\hline \multirow{2}{*}{ Element } & Source & $\mathrm{df}$ & $\mathrm{SS}$ & $F$ & $\mathrm{p}$ \\
\hline $\mathrm{Na} / \mathrm{Ca}$ & Site & 3 & 0.595 & 48.971 & $<0.001$ \\
& Error & 78 & 0.316 & & \\
$\mathrm{Mg} / \mathrm{Ca}$ & Site & 3 & 16.158 & 14.656 & $<0.001$ \\
& Error & 78 & 28.665 & & \\
$\mathrm{~K} / \mathrm{Ca}$ & Site & 3 & 7.637 & 95.083 & $<0.001$ \\
& Error & 78 & 2.088 & & \\
$\mathrm{Cu} / \mathrm{Ca}$ & Site & 3 & 0.0338 & 46.759 & $<0.001$ \\
& Error & 78 & 0.0188 & & \\
$\mathrm{Sr} / \mathrm{Ca}$ & Site & 3 & 1.553 & 15.549 & $<0.001$ \\
& Error & 78 & 2.597 & & \\
$\mathrm{Ba} / \mathrm{Ca}$ & Site & 3 & 0.0222 & 64.646 & $<0.001$ \\
& Error & 78 & 0.0089 & & \\
\hline
\end{tabular}

Table 3. Clupea pallasii. Results of ANOVA for each element (molar ratio to calcium) in the otoliths of 3 sampling groups (Akkeshi Bay, Lake Furen, Miyako Bay) of the 2006 year class

\begin{tabular}{|lccccc|}
\hline \multirow{2}{*}{ Element } & Source & df & SS & $F$ & $p$ \\
\hline $\mathrm{Na} / \mathrm{Ca}$ & Site & 2 & 0.846 & 117.94 & $<0.001$ \\
& Error & 55 & 0.197 & & \\
$\mathrm{Mg} / \mathrm{Ca}$ & Site & 2 & 12.23 & 7.658 & $<0.01$ \\
& Error & 55 & 43.916 & & \\
$\mathrm{~K} / \mathrm{Ca}$ & Site & 2 & 12.148 & 409.79 & $<0.001$ \\
& Error & 55 & 0.815 & & \\
$\mathrm{Cu} / \mathrm{Ca}$ & Site & 2 & 0.0296 & 118.47 & $<0.001$ \\
& Error & 55 & 0.0069 & & \\
$\mathrm{Sr} / \mathrm{Ca}$ & Site & 2 & 0.566 & 9.172 & $<0.001$ \\
& Error & 55 & 1.698 & & \\
$\mathrm{Ba} / \mathrm{Ca}$ & Site & 2 & 0.0031 & 16.086 & $<0.001$ \\
& Error & 55 & 0.0053 & & \\
& & & & & \\
\hline
\end{tabular}

knife cross-validation ranged from 87 to $100 \%$ for the 4 sampling groups (Table 4a). When the fish from Ishikari Bay in March and May were combined, the classification accuracy changed to a range of 80 to $98 \%$ (Table 4b). Since otolith elemental compositions of fish from Ishikari Bay in March and May showed little misclassification to the other fish groups, the monthly variation would not prevent the interpretation of geographic differences of otolith chemistry among fish groups. Likewise, in the 2006 year class, the classification accuracy ranged from 78 to $100 \%$ (Table 4c).

\section{DISCUSSION}

In addition to environmental factors such as temperature, salinity and elemental compositions, factors such as ontogenic and physiological effects have also been found to influence otolith elemental composi-
Table 4. Clupea pallasii. Cross-validated classification rates $(\%)$ for quadratic discriminant function analysis undertaken for 7 sampling groups taken from 5 sampling sites along the northern coast of Japan using 6 variables $(\mathrm{Na} / \mathrm{Ca}, \mathrm{K} / \mathrm{Ca}, \mathrm{K} / \mathrm{Ca}$, $\mathrm{Cu} / \mathrm{Ca}, \mathrm{Sr} / \mathrm{Ca}$ and $\mathrm{Ba} / \mathrm{Ca}$ ). (a) Classification accuracies among the 4 sampling groups in the 2005 year class. (b) Results for the 3 remaining 2005 year class groups when the 2 fish groups from Ishikari Bay in March and May are combined. (c) Results for the sampling groups in the 2006 year class. Values in bold indicate the rates of correct classification to the captured sites and were used for the evaluation of the ability of otolith elemental compositions to discriminate habitat differences in Pacific herring. A: Akkeshi Bay; I-Mar: Ishikari Bay in March; I-May: Ishikari Bay in May; I: Ishikari Bay in March and May; M-Jan: Miyako Bay in January; M-Mar: Miyako Bay in March; F: Lake Furen; T: Tomamae offshore

\begin{tabular}{|lcccc|}
\hline (a) 2005 year class & I-Mar & M-Jan & I-May & T \\
\hline I-Mar & $\mathbf{9 0}$ & 5 & 5 & 0 \\
M-Jan & 13 & $\mathbf{8 7}$ & 0 & 0 \\
I-May & 0 & 0 & $\mathbf{1 0 0}$ & 0 \\
T & 5 & 5 & 0 & $\mathbf{9 0}$ \\
(b) 2005 year class & I & M-Jan & T & \\
\hline I & $\mathbf{9 8}$ & 2 & 0 & \\
M-Jan & 20 & $\mathbf{8 0}$ & 0 & \\
T & 10 & 5 & $\mathbf{8 5}$ & \\
(c) 2006 year class & $\mathrm{A}$ & $\mathrm{F}$ & M-Mar & \\
\hline A & $\mathbf{7 8}$ & 0 & 22 & \\
F & 0 & $\mathbf{1 0 0}$ & 0 & \\
M-Mar & 11 & 0 & $\mathbf{8 9}$ & \\
\cline { 1 - 3 } & & & & \\
\end{tabular}

tions in some species of fish (Kalish 1989, Otake et al. 1994, Chittaro et al. 2006). In the present study, we minimized the ontogenetic effects on the otolith chemistry by using fishes of particular year classes to examine the geographic variations among sampling groups. Physiological influences resulting from reproductive activity were also considered to be minimal, because only fish of similar reproductive development (only high GSI value) were analyzed. Further study will be needed to understand the mechanisms that may influence the elemental composition of fish otoliths. However, as reported by Campana et al. (1994) and Thorrold et al. (1998a), elemental signatures as natural tags of habitat are practical enough, even if the mechanisms of compositional control are not perfectly understood.

A monthly variation in otolith chemistry was found between Pacific herring collected in Ishikari Bay in March and May in the 2005 year class, although it did not affect the interpretation of the spatial variation in otolith chemistry. The variation appears to be due to the notable environmental changes caused by the input of melted snow into the bay via rivers during spring. Le et al. (2006) reported that the flow rate of the Ishikari 
River in April was $<500 \mathrm{~m}^{3} \mathrm{~s}^{-1}$, while the flow rate in May increased remarkably to $\sim 2000 \mathrm{~m}^{3} \mathrm{~s}^{-1}$. Such large inputs of melted snow probably to result in drastic changes in temperature, salinity and water chemistry and may be the cause of monthly variations in otolith chemistry between months in the Ishikari Bay population. Further information on the monthly changes in water environment, and the monthly/seasonal changes in otolith chemistry of specific fish populations in relation to these environmental changes, is required.

In the present study, the classification accuracies for otolith chemistry, based on QDFA, were similar to those of other studies in which the natal or nursery sites of fish collected in estuarine and riverine systems were determined. For example, juvenile weakfish Cynoscion regalis were classified to their natal estuaries with $63 \%$ success (Thorrold et al. 1998a); juvenile American shad Alosa sapidissima were classified to their natal river with $90 \%$ success (Thorrold et al. 1998b); and juvenile trumpeter Pelates sexineatus were classified to their estuarine nursery habitat with $75 \%$ success (Gillanders \& Kingsford 2000). Some studies have examined the ability of otolith chemistry to discriminate habitat differences in coastal or openocean environments. Pacific bluefin tuna Thunnus orientalis spawned in the Pacific Ocean were classified with $100 \%$ accuracy, but those from the East China Sea, including 3 year classes, were classified to each year class with $<50 \%$ success (Rooker et al. 2001). Success in the classification of adult Patagonian toothfish Dissostichus eleginoides according to capture sites in a fully marine environment ranged from 50 to $84 \%$ (Ashford et al. 2005). The classification success determined in previous studies using otolith elemental compositions was comparable to that we found in the present study for Pacific herring. We conclude that otolith chemistry in Pacific herring records habitat differences among marine areas.

Our findings in the present study indicated that otolith chemistry is a potential tool for identifying groups of Pacific herring with different histories of habitat use and with different migration patterns. The information on population structure and migration patterns that can be provided by otolith chemistry is likely to be useful in helping to establish an effective fishery management strategy for Pacific herring. The results of the present study will also contribute to developing a reliable method of stock identification using otolith chemistry.

Acknowledgements. We thank M. J. Miller for helpful comments on a draft of this manuscript. We thank 3 anonymous reviewers for their helpful comments on this paper. This work was supported in part by Grants-in-Aid Nos. 18780141, 2068808 and 21380122 from the Ministry of Education, Culture, Sports, Science, and Technology of Japan.

\section{LITERATURE CITED}

Arai T, Otake T, Tsukamoto K (1997) Drastic changes in otolith microstructure and microchemistry accompanying the onset of metamorphosis in the Japanese eel Anguilla japonica. Mar Ecol Prog Ser 161:17-22

> Arai T, Kotake A, Lokman PM, Miller MJ, Tsukamoto K (2004) Evidence of different habitat use by New Zealand freshwater eels Anguilla australis and A. dieffenbachii, as revealed by otolith microchemistry. Mar Ecol Prog Ser 266: $213-225$

> Ashford JR, Jones CM, Hofman E, Everson I, Moreno C, Duhamel G, Williams R (2005) Can otolith elemental signature record the capture site of Patagonian toothfish Dissostichus eleginoides, a fully marine fish in the southern ocean? Can J Fish Aquat Sci 62:2832-2840

Bath GE, Thorrold SR, Jones CM, Campana SE, McLaren JW, Lam JWH (2000) Strontium and barium uptake in aragonitic otoliths of marine fish. Geochim Cosmochim Acta 64: 1705-1714

Campana SE, Fowler AJ, Jones CM (1994) Otolith elemental fingerprinting for stock identification of Atlantic cod Gadus morpha using laser ablation ICP-MS. Can J Fish Aquat Sci 51:1942-1950

Chittaro PM, Hogan JD, Gagnon J, Fryer BJ, Sale PF (2006) In situ experiment of ontogenic variability in the otolith chemistry of Stegastes prtitus. Mar Biol 149: 1227-1235

Elsdon TS, Gillanders BM (2002) Interactive effect of temperature and salinity on otolith chemistry: challenges for determining environmental history of fish. Can J Fish Aquat Sci 59:1796-1808

Fowler AJ, Campana SE, Jones CM, Thorrold SR (1995) Experiment assessment of the effect of temperature and salinity on elemental composition of otoliths using solutionbased ICPMS. Can J Fish Aquat Sci 52:1421-1430

Gillanders BM (2002) Temporal and spatial variability in elemental composition of otoliths: implications for determining stock identity and connectivity of populations. Can J Fish Aquat Sci 59:669-679

Gillanders BM, Kingsford MJ (1996) Elements in otoliths may elucidate the contribution of estuarine recruitment to sustaining coastal reef populations of a temperate reef fish. Mar Ecol Prog Ser 141:13-20

Gillanders BM, Kingsford MJ (2000) Elemental fingerprints of otoliths of fish may distinguish estuarine nursery habitats. Mar Ecol Prog Ser 201:273-286

> Grant WS, Utter FM (1984) Biochemical population genetics of Pacific herring Clupea pallasii. Can J Fish Aquat Sci 41:856-864

Hay DE (1985) Reproductive biology of Pacific herring Clupea harengus pallasii. Can J Fish Aquat Sci 42:111-126

> Hay DE, McCenter PB, Daniel KS (2001) Tagging of Pacific herring Clupea pallasii from 1936-1992: a review with comment on homing, geographic fidelity, and staying. Can J Fish Aquat Sci 58:1356-1370

Hoff GR, Fuiman LA (1995) Environmentally induced variation in elemental composition of red drum Sciaenops ocellatus otoliths. Bull Mar Sci 56:578-591

Iizuka A, Morita S (1991) Review of herring fishery and its biological research in Japan. Mar Freshwat Behav Physiol 18:227-302

Kalish JM (1989) Otolith microchemistry: validation of the effects of physiology, age and environment on otolith composition. J Exp Mar Biol Ecol 132:151-178

Kanno Y (1989a) Variation in meristic and morphometric characters among populations of herring Clupea pallasii 
in the far eastern waters. Bull Jpn Soc Sci Fish 55:431-439 (in Japanese with English abstract)

Kanno Y (1989b) Comparison of age composition, sex ratio and growth rate among populations of herring Clupea pallasii in the far eastern waters. Bull Jpn Soc Sci Fish 55:583-589 (in Japanese with English abstract)

Kobayashi T, Iwata M, Numachi K (1990) Genetic divergence among local spawning populations of Pacific herring in the vicinity of northern Japan. Bull Jpn Soc Sci Fish 56:1045-1052 (in Japanese with English abstract)

Koya Y, Soyano K, Yamamoto K, Obana H, Matsubara T (2003) Oocyte development and serum profiles of vitellogenin and steroid hormone levels in captive female Pacific herring Clupea pallasii during their first maturational cycle. Fish Sci 69:137-145

Le VS, Yamashita T, Okunishi T, Shinohara R, Miyatake M (2006) Characteristics of suspended sediment material transport in the Ishikari Bay in snowmelt season. Appl Ocean Res 28:275-289

Limburg KE (1995) Otolith strontium traces environmental history of subyearling American shad Alosa sapidissima. Mar Ecol Prog Ser 119:25-35

Martin GB, Thorrold SR (2005) Temperature and salinity effect on magnesium, manganese, and barium incorporation in otoliths of larval and early juvenile spot Leiostomus xanthurus. Mar Ecol Prog Ser 293:223-232

Milton DA, Chenery SR, Farmer MG, Blaber SJM (1997) Identifying the spawning estuaries of the tropical shad, terubok Tenualosa toil, using otolith microchemistry. Mar Ecol Prog Ser 153:283-291

Nagasawa K (2001) Long-term variations in abundance of Pacific herring Clupea pallasii in Hokkaido and Sakhalin related to change in environmental conditions. Prog Oceanogr 49:551-564

Otake T, Ishii T, Nakahara M, Nakamura R (1994) Drastic changes in otolith strontium/calcium ratios in leptocephali and glass eels of Japanese eel Anguilla japonica. Mar Ecol Prog Ser 112:189-193

Rooker JR, Secor DH, Zdanowicz VS, Itoh T (2001) Discrimination of northern bluefin tuna from nursery areas in the Pacific Ocean using otolith chemistry. Mar Ecol Prog Ser 218:275-282

Editorial responsibility: Hans Heinrich Janssen, Oldendorf/Luhe, Germany
Ruttenberg BI, Warner RR (2006) Spatial variation in the chemical composition of natal otolith from a reef fish in the Galapagos islands. Mar Ecol Prog Ser 328: $225-236$

- Secor DH, Rooker JR, Zlokovitz E, Zdanowicz VS (2001) Identification of riverine, estuarine, and coastal contingent of Hudson River striped bass based upon otolith elemental fingerprints. Mar Ecol Prog Ser 211:245-253

Shirai $\mathrm{K}$, Kawashima $\mathrm{T}$, Sowa $\mathrm{K}$, Watanabe $\mathrm{T}$ and others (2008a) Minor and trace element incorporation into branching coral Acropora nobilis skeleton. Geochim Cosmochim Acta 72:5386-5400

Shirai K, Takahata N, Yamamoto H, Omata T, Sasaki T, Sano Y (2008b) Novel analytical approach to bivalve shell biogeochemistry: a case study of hydrothermal mussel shell. Geochem J 43:413-420

Sugaya T, Sato M, Yokoyama E, Nemoto Y and others (2008) Population genetic structure and variability of Pacific herring Clupea pallasii in the stocking area along the Pacific coast of northern Japan. Fish Sci 74: 579-588

> Thorrold SR, Jones CM, Swart PK, Targett TE (1998a) Accurate classification of juvenile weakfish Cynoscion regalis to estuarine nursery areas based on chemical signature in otolith. Mar Ecol Prog Ser 173:253-265

Thorrold SR, Jones CM, Campana SE, McLaren JW, Lam JWH (1998b) Trace element signatures in otolith record natal river of juvenile American shad Alosa sapidissima. Limnol Oceanogr 43:1826-1835

- Thorrold SR, Latkoczy C, Swart PK, Jones CM (2001) Natal homing in a marine fish metapopulation. Science 291: 297-299

Townsend DW, Radtke RL, Corwin S, Libby D (1992) Strontium:Calcium ratios in juvenile Atlantic herring Clupea harengus L. otoliths as a function of water temperature. J Exp Mar Biol Ecol 160:131-140

Tunheng A, Hirata T (2004) Development of signal smoothing device for laser ablation-ICP-mass spectrometer. J Anal At Spectrom 19:932-934

Underwood AJ (1999) Experimental in ecology: their logical design and interpretation using analysis of variance. Cambridge University Press, Cambridge

Submitted: March 10, 2010; Accepted: September 13, 2010 Proofs received from author(s): October 8, 2010 